$14^{\text {th }}$ Conf. Agric. Develop. Res., Fac. Agric., Ain Shams Univ.,

March, 2019, Cairo, Egypt

Special Issue, 27(1), 553 - 561, 2019

Website: http://strategy-plan.asu.edu.eg/AUJASCI/

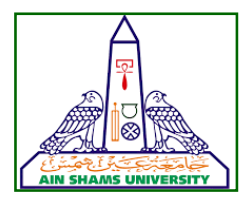

\title{
ISOLATION, IDENTIFICATION AND MOLECULAR CHARACTERIZATION OF PECTINASE PRODUCING BACTERIAL ISOLATE Klebsiella oxytoca
}

\author{
[52] \\ Nagwa. M. Abdel-Aziz ${ }^{1}$, Atallah A.G. ${ }^{1}$, Abdel-Aal, S.Kh. ${ }^{1}$, Mohamed, E.A.
Ibrahim, S.A. ${ }^{2}$ and Zein Elabedeen A. ${ }^{2}$ \\ 1. Genetic Microbial Dept., National Research Center, Dokki, Giza, Egypt \\ 2. Genetic Dept., Fac. of Agric., Ain Shams Univ., P.O. Box 68, Hadyek Shoubra 11241, Cairo, \\ Egypt
}

*Corresponding author: nagwakh@yahoo.com

Received 11 November, 2018,

Accepted 27 November, 2018

\begin{abstract}
Twenty two bacteria were isolated from soil samples local. were assayed for pectinolytic activity after optimization condition for pectinase production. isolate No. 22 showed high pectinase specific activity $(91.4 \mathrm{U} / \mathrm{ml})$ on glucose supplemented medium. the identification of the isolate revealed that it belongs to the Genus klebseilla bassed on morphological, biochemical characteristic, growth and molecular level 16s rRNA indicated that isolate was $99 \%$ similarity with Klebsiella oxytoca JKo3. Therefore, it was named Klebsiella oxytoca N22.
\end{abstract}

Key words: Pectin, Pectinase, Pectinase producing bacterial Klebsiella oxytoca.

\section{INTRODUCTION}

Enzymes are biocatalysts which are synthesized by living cells. It is also defined as the catalyst that increases the velocity or rate of a chemical reaction. Microbial enzymes are routinely used in many environment friendly and economic industrial sectors (Hoondal et al 2002). Microbes are the best source of enzymes as they allow an economical technology with low resource consumption and low emission involving no social and political issues, as in the case of animal and plant sources (Dalvi et al 2007).

Pectic substances, are acidic structural polysaccharides in the middle lamella and primary cell wall of higher plants or a major constituent of cereals, vegetables, fruits, and fibers, is a complex, heterogeneous, Aaisha and Barate 2016, pectins are glycosidic macromolecules with high molecular weight (Mei et al 2013 and Raju and Divakar 2013).

The main chain of pectin is partially methyl esterified 1,4-D-glacturonan. Demethylated pectin is known as pectic acid (pectate) or polygalacturonic acid. (Rokade et al 2015 and Famotemi et al 2015).

Pectic substances are basically classified into four main types based on the type of modifications of the backbone chain. They are, Protopectin, Pectic acid, Pectinic acid and Pectin (Kashyap et al 2001 and Kumari et al 2013).

This complex carbohydrate of pectin is degraded by an extracellular enzymatic complex called pectinase (Mei et al 2013).

Pectinase (EC 3.2.1.15) are the enzymes belongs to the class hydrolase which are able to hydrolyse pectin known as pectic enzymes Sidevi et al 2016 that breakdown pectin polysaccharide substrate found in the cell walls of plant tissues through de-polymerization and de-esterification reactions into simpler molecules like sugar and other useful compounds (Aaisha and Barate 2016; Tripathi et al 2014 and Raju and Divakar 2013).

Pectinases are produced by many organisms such as animals, plants, bacteria, yeasts and Fungi, insects, nematodes, protozoan and plants. 
Among the various pectinase sources, bacterial extracellular pectinase are the most significant, compared with animals, plants, viruses and fungal extracellular pectinase (Aaisha and Barate 2016 and Famotemi et al 2015).

Microbial Pectinases account for $10-25 \%$ of the global worldwide production of enzymes or the food and industrial enzyme sales and their market is increasing day by day Raju and Divakar 2013.

The genus Bacillus and Coccic contains a number of industrially important species and approximately half of the present commercial production of bulk enzymes derives from the single class of enzymes which play an important part in the metabolism of almost all organisms (Raju and Divakar 2013).

The largest industrial application of pectinase is in food industries for fruit juice extraction and clarification. Pectins contribute to fruit juice viscosity and turbidity, jams, jellies, sauces, ketchups, flavoured syrups, desserts and other food industries. A mixture of pectinases and amylases is used to clarify fruit juices, it decreases filtration time up to $50 \%$. treatment of fruit pulps with pectinases also showed an increase in fruit juice volume from banana, grapes and apples. Pectinases are also used in industries for textile processing and bioscouring of cotton fibers, for degumming of plant bast fibers, retting of plant fibers, in waste water treatment, in coffee and tea fermentation, cocoa and tobacco, Recycling of wastepaper in paper and pulp industry, Also (Singh et al 2012) reported that, in dairy industries, these are used to prevent the formation of casein clumps for improvement of chromaticity and stability of red wines and other foods. The main objective of this work is to isolation, characterization and molecular identification of the best pectinase producing bacteria and optimization condition for pectinase production.

The main objective of this work is to isolation, characterization and molecular identification of the best pectinase producing bacteria and optimization condition for pectinase production.

\section{MATERIALS AND METHODS}

\section{1- Soil samples}

2- Preparation of soil samples

3- Pectinase medium

3.1 Pectinase screening agar medium (PSAM): Basic medium used for pectinase screening according to (Rokade et al 2015) contained (G/L)

\subsection{Pectinase screening method}

The isolates were screened for pectinase activity this was done by sterile PSAM plates were prepared and all bacterial isolates were spot inoculated on those plates. according to Raju and Divakar, 2013 and Rokade et al 2015. A clear zone around the growth of the bacteria indicate the strains which are able to utilize pectin as a source of carbon develop colony on PSAM medium and were selected as positive cultures.

3.3 Pectinase production medium (Tripathi et al 2014) contained (G/L). Inoculume preparation: experimental was conducted in $250 \mathrm{ml}$ capacity conical flasks contained $50 \mathrm{ml}$ of the above medium. And autoclaved at $121^{\circ} \mathrm{C}$ for 15 min..the culture were inoculated with prepared inoculum.

\section{4- 16S rDNA universal primers}

The universal primer set used was synthesized through Sigma Scientific Services Co. They are:

Forward primer (FP)

5'AGAGTTTGATCATGGCTCAG-3'

Reverse primer (RP) 5'- GGTTACCTTGTTACGACTT-3'.

\section{5- Agarose gel electrophoresis}

TBE buffer (5X), Loading buffer and ethedium bromide according to Sambrook and Russell, 2001

6- Collection and isolation of pectinolytic microorganisms according to Aaisha and Barate 2016.

\section{7- Pectinolytic isolates identification}

\subsection{Biochemical identification of bacterial iso- lates}

The twenty two local isolates, which obtained were characterized morphologically, physiologically and biochemically according to John and Bergy (1993).

\subsection{Molecular identification of bacterial isolate}

The 16S rDNA region was partially amplified by polymerase chain reaction (PCR) and sequenced. Crude lysate of cell (fresh prepared) was obtained and subjected to PCR amplification using the universal primer (Delta Company).

\section{8- Electrophoresis}


A sample of PCR product was analyzed using agarose gel electrophoresis and compared with $1 \mathrm{~Kb}$ Ladder DNA marker (250 bp - 10000 bp) (AXYGEN).

\section{9- Sequencing of purified 16s rDNA gene}

Finally sequencing to the $\mathrm{PCR}$ product on GATC company by $\mathrm{ABI} 3730 \mathrm{xl}$ DNA sequencer using forward and reverse primers.

\section{0- Pectinase relative growth production (C/G)}

Pectin agar plates were inoculated with tested bacterial strains and incubated at $37^{\circ} \mathrm{C}$ for $48 \mathrm{~h}$. Developed colonies surrounded by clear zones were selected as pectinase positive strains as described by Rokade et al (2015). Three measurements were used to determine the enzyme relative growth production as described by Solaiman et al2005.
11- Productivity of pectinase enzyme, pectinase assay and protein content were determined by the method of Tripathi et al 2014

12- Study of growth parameters of isolates showing maximum pectinase production well be done according to the method described by Khan and Barate (2016).

\section{RESULTS AND DISCUSSION}

\section{Isolation of pectinolytic bacteria}

Many purified colonies were screened for their pectinolytic activity using pectin agar medium. 22 isolates showed clear zones surrounding their growth as indication for their ability to degrade pectin as shown in Fig. (1).

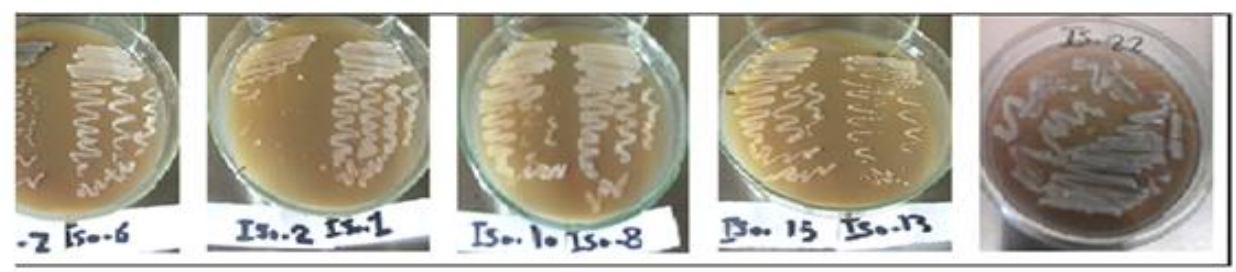

Fig.1. Colony morphology of some isolates

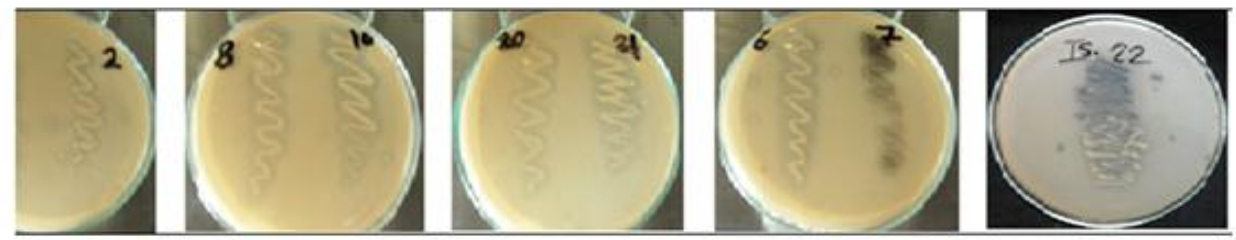

Fig.1. Pectinase activity of some isolates as indicated by clear zones surrounding bacterial growth on pectinase screening agar medium (PSAM) plates $48 \mathrm{~h}$ post incubation at $37^{\circ} \mathrm{C}$

Table 1. Pectinase activities of different bacterial isolates.

\begin{tabular}{|c|c|c|c|c|c|c|c|}
\hline $\begin{array}{c}\text { Isolate } \\
\text { No. }\end{array}$ & $\begin{array}{c}\text { Pectinase } \\
\text { activity (U/mI) }\end{array}$ & $\begin{array}{c}\text { Total } \\
\text { protein } \\
\text { (mg/ml) }\end{array}$ & $\begin{array}{c}\text { Relative } \\
\text { growth pro- } \\
\text { duction (C/G) }\end{array}$ & $\begin{array}{c}\text { Iso- } \\
\text { late } \\
\text { No. }\end{array}$ & $\begin{array}{c}\text { Pectinase } \\
\text { activity } \\
\text { (U/ml) }\end{array}$ & $\begin{array}{c}\text { Total } \\
\text { protein } \\
\text { (mg/ml) }\end{array}$ & $\begin{array}{c}\text { Relative } \\
\text { growth pro- } \\
\text { duction (C/G) }\end{array}$ \\
\hline $\mathbf{1}$ & 36.18 & 0.462 & 21.77 & $\mathbf{1 2}$ & 5.160 & 0.531 & 18.77 \\
$\mathbf{2}$ & 4.940 & 0.387 & 11.77 & $\mathbf{1 3}$ & 6.720 & 0.657 & 15.00 \\
$\mathbf{3}$ & 4.680 & 0.440 & 11.11 & $\mathbf{1 4}$ & 3.540 & 0.375 & 10.11 \\
$\mathbf{4}$ & 28.62 & 0.295 & 15.00 & $\mathbf{1 5}$ & 48.54 & 0.717 & 25.00 \\
$\mathbf{5}$ & 6.240 & 0.524 & 16.00 & $\mathbf{1 6}$ & 5.940 & 0.284 & 18.77 \\
$\mathbf{6}$ & 52.32 & 0.789 & 25.00 & $\mathbf{1 7}$ & 9.420 & 0.554 & 18.77 \\
$\mathbf{7}$ & 6.180 & 0.572 & 17.25 & $\mathbf{1 8}$ & 3.660 & 0.480 & 11.77 \\
$\mathbf{8}$ & 61.08 & 0.831 & 32.11 & $\mathbf{1 9}$ & 6.900 & 0.671 & 15.00 \\
$\mathbf{9}$ & 5.520 & 0.499 & 15.00 & $\mathbf{2 0}$ & 15.00 & 0.522 & 18.44 \\
$\mathbf{1 0}$ & 57.96 & 0.777 & 28.00 & $\mathbf{2 1}$ & 45.06 & 0.724 & 36.00 \\
$\mathbf{1 1}$ & 5.340 & 0.418 & 18.77 & $\mathbf{2 2}$ & 64.98 & 0.798 & 12.56 \\
\hline
\end{tabular}


$(\mathrm{C} / \mathrm{G})^{*}:{ }^{*}(\mathrm{C})$ lyses zone area, $\left(\mathrm{mm}^{2}\right) ;(\mathrm{G})$ colony growth area $\left(\mathrm{mm}^{2}\right)$

As an indicator for pectinase activity, relative growth production was calculated to each bacterial isolate (Table1). The results showed different relative growth production $(\mathrm{C} / \mathrm{G})$ among the isolates ranging from 36.0 (isolate 21 ) to 10.11 (isolate 14). The most active isolates were 1, 6, 8, 10, 15, 21 and 22 which had 21.77, 25.00, 32.11, 28, 25, 36 and 12.56 in relative growth production $(C / G)$, respectively.

Pectinase specific activity was assayed for each isolate after growth in the basic medium supplemented with $1 \%$ pectin. Table (1) showed different pectinase activities among the tested isolates. The pectinase specific activities ranged between 3.5 (isolate 14) to 64.98 (isolate 22) $\mathrm{U} / \mathrm{ml}$ respectively.

The highest pectinase specific activities were found in the isolates; $1,6,8,10,15,21$, and 22 where they had $36.18,52.32,61.80,57.96,48.54$, 45.06 and $64.98 \mathrm{U} / \mathrm{ml}$, respectively. Two isolates low in pectinase specific activities were found, 2 and 7 where they had 4.940 and $6.180 \mathrm{U} / \mathrm{ml}$, respectively

In another assay of pectinase activity of the isolates, protein contents were measured as indicated by $O . D_{280}$ measurements. Protein contents ranged between 0.284 and 0.83 isolate 16 and isolate 8 respectively. The highest isolates in protein content production were No.8, 22 and 6 which produced $O . D_{280}$ of $0.831,0.798$ and 0.789 respectively.

The results in Table (1) illustrated that there is no correlation between relative growth production $(\mathrm{C} / \mathrm{G})$ and the pectinase specific activity, it also showed that isolate No. 21 and No. 22 produced 36.00 and 21.77 as relative growth production $(\mathrm{C} / \mathrm{G})$, while isolate No. 22 was more efficient in pectinase activity $(64.98 \mathrm{U} / \mathrm{ml})$ than isolate No. $21(45.06 \mathrm{U} / \mathrm{ml})$.

This result is in agreement with the results reported by Aunstrup (1974) and Soliman et al (2005). These results may due to incompatibility or differences in growth conditions, e.g., depth of agar layer can affect the diffusion of enzyme.

In agreement with the obtained results, Khan and Barate 2016 Seventy-two bacterial strains were isolated from twenty various sources including soil, water, rotten fruits, vegetables etc. Preliminary screening for pectinase producing bacterial strains was done by well plate method and twentysix bacterial strains gave zones on minimum salt (MS) medium supplemented with $0.2 \%$ pectin.
Most of the isolates belonged to plant origin, either rotten fruits or vegetables due to high pectin presence as compared to other samples. Amongst the bacterial isolates, ZP-F5 and ZP-F6 gave the largest zone sizes i.e., $45 \mathrm{~mm}$ and $40 \mathrm{~mm}$ respectively. All selected strains were subjected to cellular, morphological and biochemical characterization.

Rokade et al 2015 screen out and isolate efficient pectinase producing bacterial strains and to identify bacterial strains. Isolates were screened for pectinase production by using pectinase screening agar medium (PSAM). Six pectinase producing bacterial strains were isolated from Osmanabad soil samples of fruit market.one strain showing maximum zone was selected and this strain was identified.This strain was tested for morphological and biochemical characters and was designated as Staphylococci sp.

\section{Optimization conditions of isolates for pecti- nase production}

To identify the suitable carbon sources for pectinase production by the isolates. The following different carbon sources were tested such as glucose, sucrose, starch, lactose, xylose, and fructose with sample concentration of $0.5 \%$ in the optimized carbon sources in production medium at $37^{\circ} \mathrm{C}$.

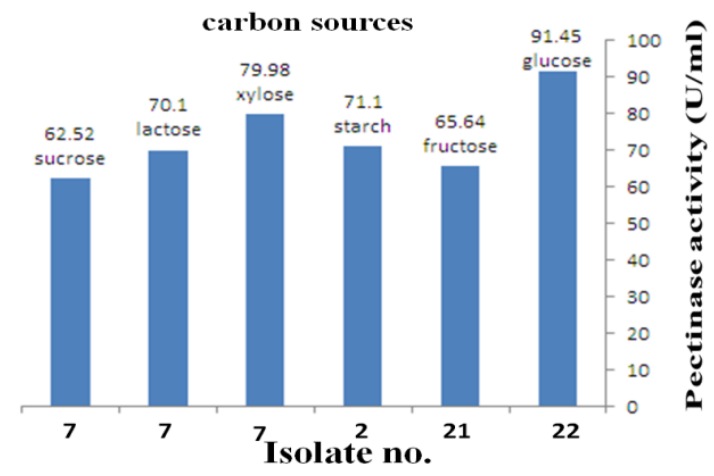

Fig. 2. Effect of carbon source on the pectinase production by sources

The maximum pectinase production were; isolates No. 22 was $(91.4 \mathrm{U} / \mathrm{ml})$ on glucose supplemented medium, isolate No. 7 was $(79,98 \mathrm{U} / \mathrm{ml})$ on xylose supplemented medium and isolate No.2 was $(71.1 \mathrm{U} / \mathrm{ml})$ on starch supplemented medium. The minimum pectinase production was isolate 


\section{Bacterial isolate Klebsiella oxytoca}

No.10 was $(11.82 \mathrm{U} / \mathrm{ml})$ recorded in sucrose supplemented medium as shown in Fig. 2.

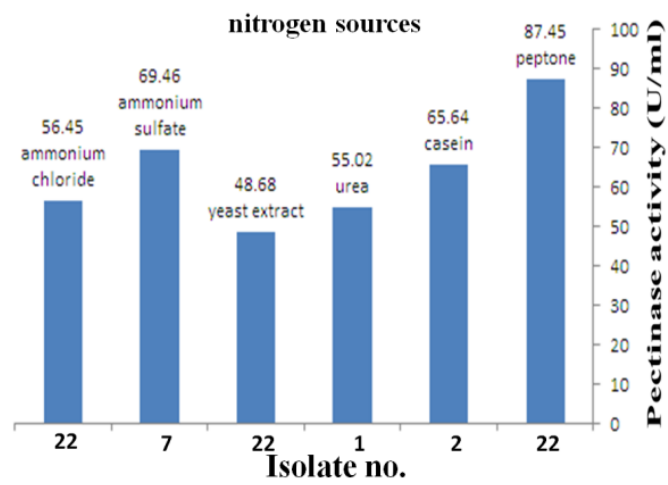

Fig. 3. Optimization conditions of isolates for pectinase production on nitrogen sources.

The pectinase production by the selected bacterium was also optimized by supplementing different organic and inorganic nitrogen sources individually at the concentration of $0.5 \%$ such as (peptone, casein, urea, yeast extract, ammonium sulfate and ammonium chloride)

The maximum pectinase production were isolates No. 22 was $(87.45 \mathrm{U} / \mathrm{ml})$ on peptone supplemented medium, isolate No. 7 was $(69.46 \mathrm{U} / \mathrm{ml})$ on ammonium sulphate supplemented medium and isolate No.2 was $(65.64 \mathrm{U} / \mathrm{ml})$ on casein supplemented medium $(71.1 \mathrm{U} / \mathrm{ml})$ on starch supplemented medium as shown in fig 3.

In agreement with the obtained results, (Kaur et al 2016) reported a total of five isolates showed pectinase production and designated as PPB1 to PPB5. Isolate PPB5 showed maximum enzyme activity of $0.641 \mathrm{IU} / \mathrm{ml}$. Pectinase activity was optimized for various parameters like incubation time, temperature, $\mathrm{pH}$, different carbon and nitrogen sources. Enzyme activity was observed maximum at $96 \mathrm{hr}$ of incubation, $35^{\circ} \mathrm{C}$ temperature and at $\mathrm{pH}$ 6 . The best carbon was found to be glucose. Among organic and inorganic nitrogen sources yeast extract and ammonium nitrate was found to be better than other nitrogen sources. Among the five isolates, the isolate PPB5 showed maximum activity at all optimum conditions.

\section{Pectinolytic isolate identification}

The highest pectinase active isolate found in this study after optimization experiments was No. 22 , and it was identified morphologically, physiologically and biochemically according to John and Bergy (1993). Table (2) represent the results ob- tained. Light micrographs showed that the selected isolate No. 22 is gram-negative and belongs to the Genus klebseilla.

Table 2. Biochemical tests and characterization of high isolates

\begin{tabular}{|c|c|c|c|}
\hline Test & Result & Test & Result \\
\hline Grame stain & - & Acid from : & + \\
Shape & Circular & D-glucose & + \\
Color & Cream & L-arabinose & + \\
Elevation & Flat & D-xylose & + \\
Surface & Smooth & D-sucrose & + \\
Citrate & + & D-fructose & + \\
Tyrosein & + & D-galactose & + \\
Starch hydrolysis & + & D-lactose & + \\
Nutrient agar & + & D-mannose & \\
$(2 \% N a C l)$ & & & \\
Nutrient agar & + & Caseinase & + \\
$(5 \% N a C l)$ & & & \\
Nutrient agar & + & Urease & + \\
$(7 \% N a C l)$ & & Manitol salt & - \\
Nutrient agar & - & Indol & + \\
$(10 \% N a C l)$ & & agar (MSA & \\
Nutrient agar $\left(4^{\circ} \mathrm{C}\right)$ & - & Catalase & \\
Nutrient agar $\left(30^{\circ} \mathrm{C}\right)$ & + & Lipase & - \\
Nutrient agar $\left(55^{\circ} \mathrm{C}\right)$ & - & Oxidase & + \\
Voges proskaour/MR & + & Gelatin & + \\
Nutrient agar $(\mathrm{pH} 5.7)$ & + & & + \\
Nutrient agar $\mathrm{pH} 6.8$ & + & & \\
\hline
\end{tabular}

+ Positive reaction; - negative reaction

Nine isolates No.1, 2, 6, 7, 8,10,15,21 and 22 were characterized by $16 \mathrm{~S}$ rRNA via amplification. Fig. (4) showed the successful 16S rRNA amplification of the isolate which produce about $1500 \mathrm{bp}$ amplicon.

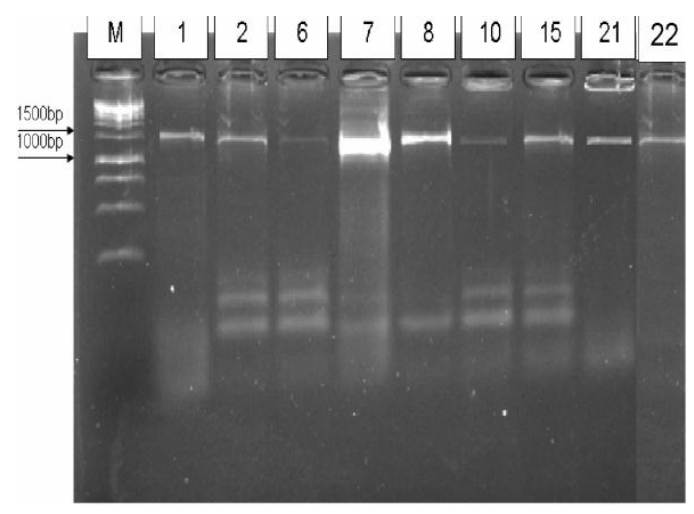

Fig. 4. Agarose gel electrophoreses of $16 \mathrm{~S}$ rRNA amplification of some isolates lane $\mathrm{M}, 1 \mathrm{~kb}$ DNA ladder; Isolate No. 22 16S rRNA amplicon. 
The amplified product of high isolate No. 22 was the highest in pectinase activity purified and its nucleotide sequence was determined by GATC company using $\mathrm{ABI} 3730 \mathrm{xl}$ DNA sequencer by forward and reverse primers. The sequence was aligned using clustalX program and the phylogenetic tree was booted by MEGA3 softwar. Fig. (5) represents the obtained sequence. This sequence was compared with other related sequences available in GenBank.
Alignment in GenBank (Blast) indicated that the isolate No. 22. 16S rRNA was 99\% similar with 16S rRNA Klebsiella oxytoca JKo3 as shown in Fig. (6).

Phylogenetic analysis based on 16S rRNA sequences showed that the isolate No.2 is closely related to Klebsiella oxytoca JKo3 (Fig.7) therefore it was named Klebsiella oxytoca N22 and used for further studies. AGGTTTCGTAGAGCATGAACCTGGCTCAGGAGCTCAGTAGCGCGGGAGCCGGAGTGACTAG-
TGGCGGACGGGTGAGTAATTCTGGGAACTGCCTGATGGAGGGGGATAACTACTGGAAACGG-
TAGCTAATACCGCATAACGTCGCAAGACCAAAGAGGGGACCTTCGGGCCTCTT-
GCCATCAGATGTGCCCAGATGGGATTAGCTAGTAGGTGGGGTAACGGCTCACCTAGGCGAC-
GATCCCTAGCTGGTCTGAGAGGATGACCAGCCACACTGGAACTGAGACACGGTCCAGACTCC-
TACGGGAGGAGCAGTGGGGAAATTGCACAATGGGCGCAA-
GCCTGATGCAGCCATGCCGCGTGTATGAAGAAGGCCTTCGGGTTGTAAAGTACTTTCAGCGGG-
GAGGAAGGCAATAAGGTTAATAACCTTGTCGATTGACGTTACCCGCAGAAGAAGCAC-
CGGCTAACTCCGTGCCAGCAGCCGCGGTAATACGGAGGGTGCAAGCGTTAATCG-
GAATTACTGGGCGTAAAGCGCACGCAGGCGGTCTGTCAAGTCG-
GATGTGAAATCCCCGGGCTCAACCTGGGAACTGCATTCGAAACTGGCAGGCTGGAGTCTT-
GTAGAGGGGGGTAGAATTCCAGGTGTAGCGGTGAAATGCGTAGAGATCTGGAGGAATAC-
CGGTGGCGAAGGCGGCCCCCTGGACAAAGACTGACGCTCAGGTGCGAAAGCGTGGGGAG-
CAAACAGGATTAGATACCCTGGTAGTCCACGCTGTAAACGATGTCGACTTGGAGGTT-
GTTCCCTTGAGGAGTGGCTTCCGGAGCTAACGCGTTAAGTCGACCGCCTGGGGAGTACGGCCG-
CAAGGTTAAAACTCAAATGAATTGACGGGGGCCCGCACAAGCGGTGGAG-
CATGTGGTTTAATCGATGCAACGCGAAGAACCTTACCTACTCTTGACATCCAGAGAACTTAG-
CAGAGATGCTTTGGTGCCTTCGGGAACTCTGAGACAGGTGCTG-
CATGGCTGTCGTCAGCTCGTGTTGTGAAATGTTGGTTAAGTCCCGCAACGAGCG-
CAACCCTTATCCTTTGTTGCCAGCGGTCCGGCCGGGAACTCAAAGGAGACTGCCAGTGA-
TAAACTGGAGGAAGGTGGGGATGACGTCAAGTCATCATGGCCCTTACGAGTAGGGC-
TACACACGTGCTACAATGGCATATACAAAGAGAAGCGACCTCGCGAGAGCAAGCGGAC-
CTCATAAAGATGTCGTAGTCCGGATTGGAGTCTGCACTCGACTCCATGAAGTCGGAATCGC-
TAGTAATCGTGGATCAGAATGCCACGGTGAATACGTTCCCGGGCCTTGTACACAC-
CGCCCGTCACACCAAGGAGTGGGTTGTAATCCATCCTCCGGCTTAGTAAGTAGCAACAAGTCTGCCGTTG

Fig. 5. 16S rDNA of isolate No.22.

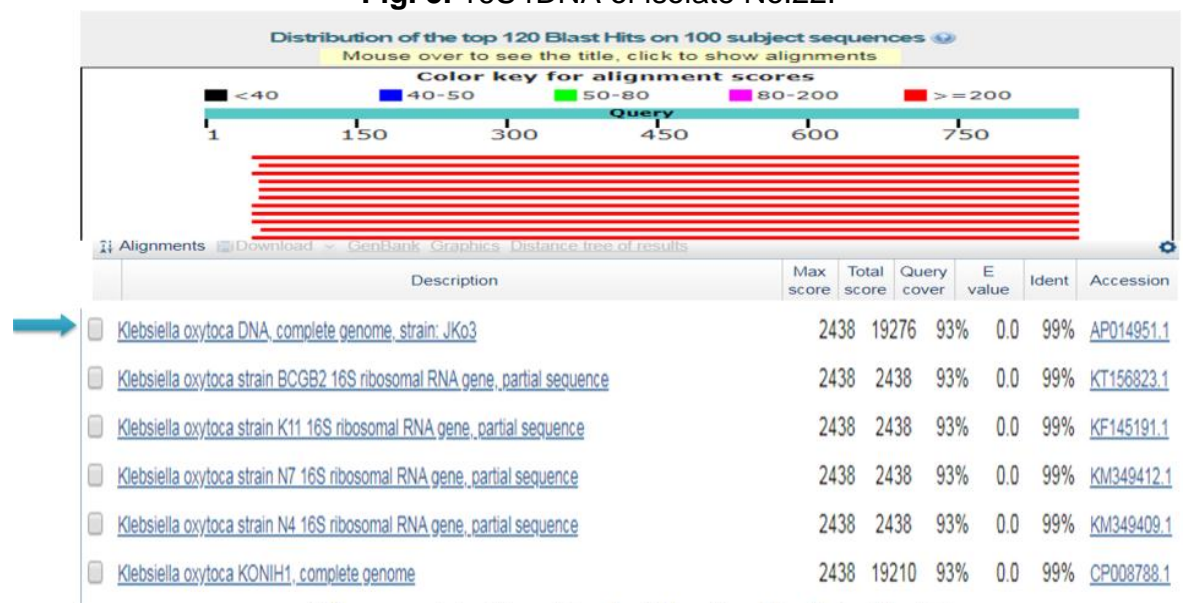

Alignment in Gen Bank (Blast) of isolate No.22 
Fig. 6. Alignment in GenBank (Blast) of isolate No.22

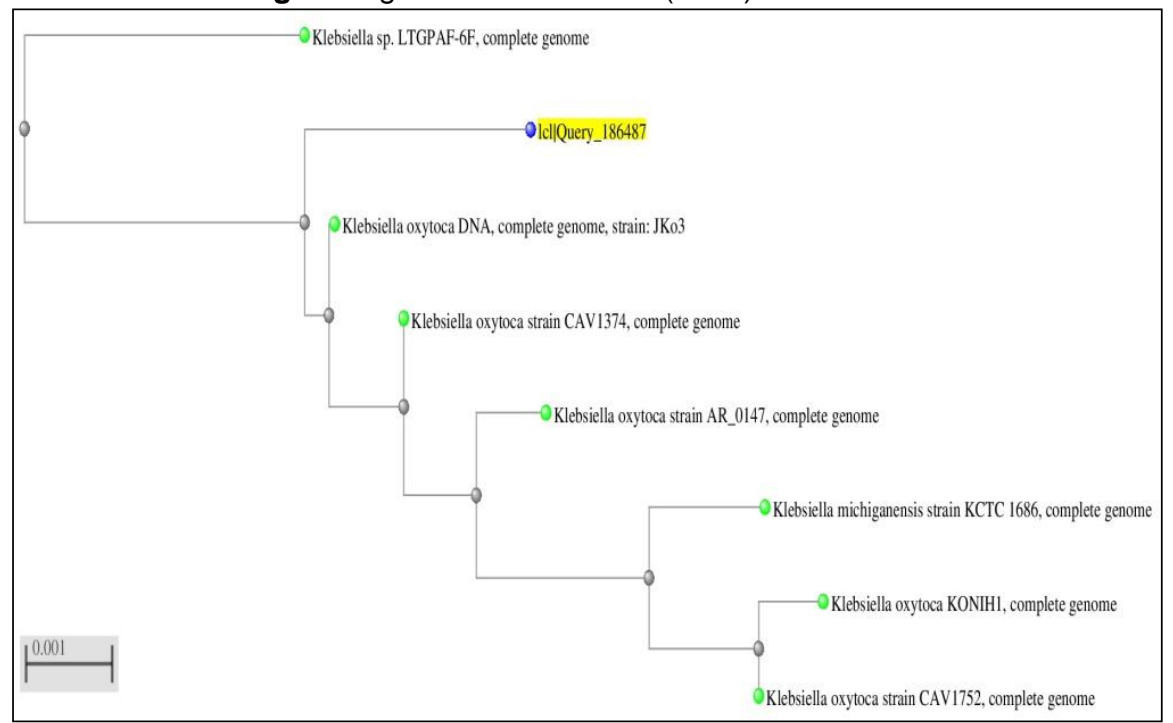

Fig 7. Phylogenetic analysis based on 16S rRNA sequences of isolate No.22.

\section{REFERENCES}

Aaisha G.A. and Barate D.L., 2016. Isolation and identification of pectinolytic bacteria from soil samples of Akola region, India Int. J. Curr. Microbiol. App. Sci., 5(1), 514-524.

Abdel-Latif H.M.A. and Wafaa H. Mohamed, 2010. Mutagenesis and inter-specific protoplast fusion between Trichoderma koningii and Trichoderma reesei for biocontrol improvement. Am. J. Sci. Ind. Res., 1(3), 504-515.

Akbar S, Prasuna R., G. and Khanam R., 2015. Strain improvement by induction of mutagenesis for hyper production of pectinase using Aspergillus tamarii. J. Sci. Ind. Res., 74(3), 160164.

Aldo J.P.D., Cinthia, Z., Marli, C. and Joao P.H. Antonio, 2006. Use of 2- deoxy glucose in liquid media for the selection of mutant strains of Penicillium echinulatum producing increased cellulase and $\beta$-glucosidase activities. Appl. Microbiol Biotechnol., 70, 740-746.

Aunstrup, K., 1974. Industrial production of proteolytic enzymes, Industrial Aspects of Biochemistry, 30(1), 23-46.

Bhargavi M., M.A. and Charya S., 2010. Influence of physical and chemical mutagens on dye decolourising Mucor mucedo. Afri J. Microbiol Res: 4(17), 1808-1813.

Chand P., Aruna A., Maqsood A.M. and Rao L.V. 2005. Novel mutation method for in- creased cellulase production. J. Appl Microbiol., 98(2), 318-323.

Dalvi, P., Anthappan, P., Darade, N., Kanoongo, N. and Adivarekar, R., 2007. Amylase and pectinase from single source for simultaneous desizing and scouring. Indian Journal Fiber Text. Res., 32, 459-465.

Famotemi, A.C., Lawal, A.K., Dike, E.N., Olatope, S.O.A., Shittu K.A., Itoandon, E.E., khinde, M.O., Orji, F.A. and Elemo, G.N., 2015. Production of pectinase from strains of Aspergillus niger using corn pomace by solid state fermentation (SSF). Int. J. Adv. Res. Biotechol., Sci. 2(5), 93-99.

Hoondal G.S, Tewari R.P., Tewari R., Dahiya N. and Beg Q.K., 2002. Microbial alkaline pectinases and their industrial applications: a review. Appl. Microbiol. Biotechnol., 5, 409418

John, G.H. and Bergy, D.H., 1993. Bergey's Manual of Determinative Bacteriology, Baltimore: Williams \& Wilkins, USA, 787 p.

Kashyap D. R, Vohra P. K, Chopra S, Tewari R., 2001. Applications of pectinases in the commercial sector: a review. Bioresour. Technol. 77, 215-227.

Kaur, S., Kaur, H.P., Prasad, B. and Bharti, T., 2016. Production and optimization of pectinase by Bacillus sp. Isolated from vegetable waste soil, Indo American Journal of Pharmaceutical Research, 6(1), 4185-4190. 
Khan I.G. and Barate D.L., 2016. Effect of various parameters on activity of pectinase enzyme. International Journal of Advanced Research, 4(1), $853-862$.

Kumari, B., Lalitha L.R., and Sudhakar, P., 2013. Studies on isolation, purification and molecular identification of pectinase producing bacteria. International J. Advanced Research, 1, (5), 204-212.

Mei, Y., Chena, B.Y., Zhaia, R. and Liua, Y. 2013. Cloning, purification and biochemical properties of a thermostable pectinase from Bacillus halodurans M29. Journal of Molecular Catalysis B: Enzymatic 94, 77-81,

Raju, E. V. N. and Divakar, G. 2013. Production of pectinase by using bacillus circulars isolated from dump yards of vegetable wastes. IJPSR, 4(7): 2615-2622,

Rokade D.D., Vaidya S.L., Rehman Naziya M.A., and Dixit. P.P., 2015. Screening of pectinase producing bacteria, isolated from Osmanabad fruit market soil, International Journal of Interdisciplinary and Multidisciplinary Studies (IJIMS), 2(6), 141-145.

Sambrook, J. and Russell, D.W., 2001. Molecular Cloning: A Laboratory Manual, Vol.1. Cold Spring Harbor Laboratory Press, USA. Science, 2344 p.
Sidevi, K., Sivaraagini, P., Sumanth, M. and Vijalakshmi. K., 2016. Isolation and screening of pectinolytic bacteria from the mango fruit yards. World Journal of Pharmacy and Pharmaceutical Sciences.5, (1)738-748.

Singh, R., Dhawan, S., Singh, K. and Kaur, J. 2012. Cloning, expression and characterization of a metagenome derived thermoactive/ thermostable pectinase. Biol. Rep., 39, 83538361.

Solaiman, E.A.M., Hegazy, W.K. and Moharam, M.E., 2005. Induction of overproducing alkaline protease Bacillus mutants through UV irradiation. Arab J. Biotech., 8(1),49-60.

Sudarshana B., Moumita K. and Rina Rani R., 2012. Increase in endoglucanase productivity and mycelial stability of Rhizopus oryzae by classical mutagenesis. Brit Biotechnol., 2(2), 60-72.

Tripathi, G., D., Javed, Z., Sushma and Singh, A.K., 2014. Pectinase production and purification from Bacillus subtilis isolated from soil. Advances in Applied Science Research, 5(1), 103-105. 


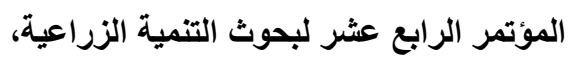

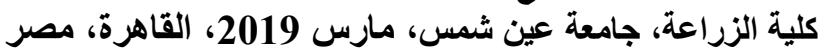

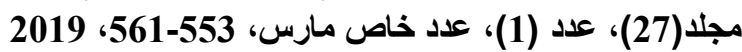

Website: http://strategy-plan.asu.edu.eg/AUJASCl/

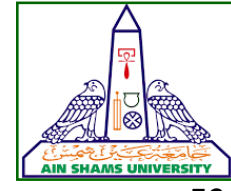

561

عزل، تعريف وتوصيف جزيئى لعزلة بكتيرية المنتجة للبكتينيز كليبسيلا

[52]

نجوى محمد عبد العزيز 1- أشرف جميل عطالله2- سمير خلف عبد العال2-- عفت عباس محمد

سمير عبد العزيز إبراهيم²- على زين العابدين

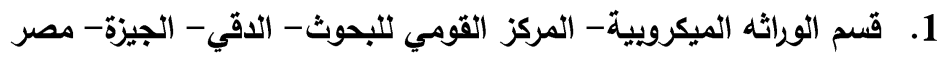

2. قسم الوراثة- كلية الزراعة- جامعة عين شسس- ص.ب 68- حدائق شبرا 11241 - القاهرة- مصر

“Corresponding author: nagwakh@yahoo.com

Received 11 November, 2018, $\quad$ Accepted 27 November, 2018

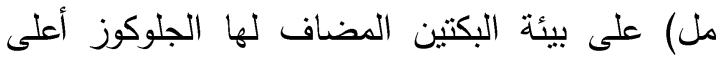
نشاط للانزيم. وتم تعريف هذه العزلة 22 على أنها

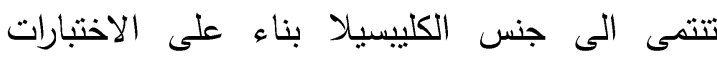

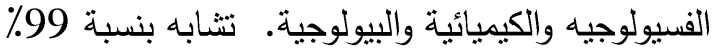

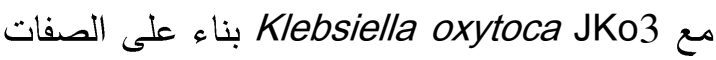
الجزيئية لجين 16srDNA، لذلك سميت Klebsiella. oxytoca $\mathrm{N} 22$

الكلمات الدالة: بكتين، بكتينيز، البكتيريا المنتجة للبكتينيز - البكات

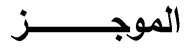

الهدف الرئيسي من هذا العمل هو عزل وتوصيف

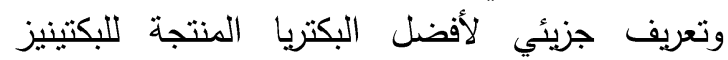

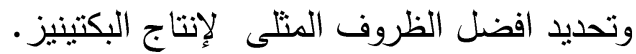

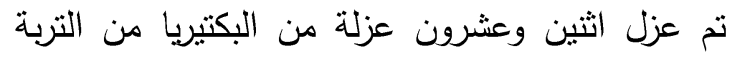

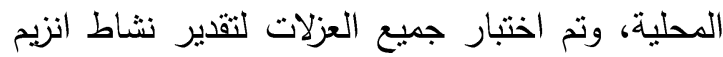
البكتينيز • وتحديد افضل الظروف المثلى لإنتاج انزيم

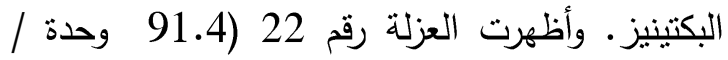

